\title{
An Analysis of Country-Related Determinants Influencing Consumer Receptivity of Foreign Products
}

\author{
Larry L. Carter ${ }^{1}$ \\ ${ }^{1}$ Utah Valley University, Orem, Utah, USA \\ Correspondence: Larry L. Carter, Utah Valley University, Woodbury School of Business, Marketing Department, \\ Orem, UT 84058-5999, USA. E-mail: larry.carter@uvu.edu
}

Received: March 11, 2014

Accepted: March 28, 2014

Online Published: May 27, 2014

doi: 10.5539/ibr.v7n6p192

URL: http://dx.doi.org/10.5539/ibr.v7n6p192

\begin{abstract}
Attempting to provide insight regarding consumers' perceptions of and purchase intentions toward foreign products, this study develops and empirically tests an inclusive model containing key determinants that affect this process. A sample of 434 university students from the United States were recruited for the study and multivariate analysis was used to assess the hypothesized effects of key country-related variables upon the stages of consumer decision-making (i.e., product evaluation, attitude formation, and purchase intention) prior to the actual purchase of a foreign product. While country-of-origin image is shown to have influence across all three stages, animosity only affects the consumer's willingness to buy the foreign product. There is evidence that consumer ethnocentrism influences both the attitude formation as well as the willingness to buy stages. These research findings suggest that marketers should take these three country-related variables under consideration when formalizing a strategy to enter a foreign market with their products. The display of packaging information must also be considered with regards to the consumer's sensitivities towards the product's country of origin.
\end{abstract}

Keywords: animosity, attitude, consumer behavior, ethnocentrism, product evaluation, willingness to buy

\section{Introduction}

\subsection{Research Problem}

The survival of a firm that manufactures and sells goods is dependent upon consumer's receptivity and purchase of those goods. Today, the majority of these businesses are faced with severe competition within both domestic as well as foreign markets. Due to the decline of trade barriers, most customers have nearly unlimited choices with regards to whom they wish to buy similar goods from. More consumers, especially those from emerging national economies (e.g., the BRIC nations of Brazil, Russia, India, and China) are entering the market with the discretionary income that allows them to purchase goods beyond the necessities (Bandyopadhyay \& Banerjee, 2002; Demir, 2013). The rapid advancements in communication over the past few decades are also bolstering the exposure of foreign goods and brands due to information dissemination. In terms of distribution, increased shipping capabilities have also added to the efficiency of acquiring foreign goods with less hassle and a shorter waiting period.

Accurately assessing foreign product receptivity is important to marketers with regards to formulating market entry strategies and developing competitive advantages; however there exists a lack of research with regards to modeling consumer receptivity toward foreign goods. The primary objective of this study is to evaluate main influences upon the consumers' willingness to buy foreign goods by identifying the key variables affecting this process. Secondly, each key variable is evaluated to determine which stages of the process are most likely influenced by the variable. The study also provides managerial applications of the findings to aid marketers in bolstering their product's appeal to foreign consumers.

\subsection{Literature Review}

Throughout the past few decades, many researchers have examined the relationship between cognitive and affective influences upon a consumer's intention to buy goods and services (e.g., Cui, Wajda, \& Hu, 2012; Li, Monroe, \& Chan, 1994; Mowen, 1995; Sharma, 2011; Wang, Li, Barnes, \& Ahn, 2012; Zajonc, 1984). The standard learning hierarchy of effects emerged from this area of research as a process of learning that humans go through, which is initiated by their formation of beliefs and subsequently leads to affect and an eventual 
behavioral act (Mowen, 1995). This theory is applicable within a marketing context with regards to consumer behavior. Shoppers develop overall evaluations about a product from both cognitive learning as well as the processing of product information from advertisements and product exposure. Over time, these consumers have collected enough information to adequately form an attitude (an enduring affect) towards the product, which in time may lead to a future purchase (a behavioral act) of that product.

Other popular models in consumer behavior directly address the relationship between attitude formation and behavioral intentions. For example, the Fishbein attitude model takes into account the number and magnitude of cognitive beliefs that are associated with an object when determining an individual's overall attitude towards that object (Fishbein \& Ajzen, 1975). Previous research also indicates that behavioral intentions influence the actual behavior. In the case of shopping behavior, these intentions are indicative of future shopping behaviors, such as the eventual purchasing of goods or perhaps even postponing the purchase (Hui \& Zhou 2002; Ulgado \& Lee, 1998).

Based on the aforementioned hierarchy of effects model and behavioral intention theory, consumer purchasing behavior is preceded by a cognitive, affective, and intention stage. With regards to foreign goods, the cognitive stage encapsulates the shopper's overall evaluation of the foreign product. The consumer then enters the affective stage of the process developing an attitude towards the foreign product. Purchase intention is the consumer's subjective judgments about future purchases which subsequently leads to the last stage, the actual purchase of the foreign product. An extensive literature review of 145 articles was conducted to uncover potential variables that directly influence these four stages. Table 1 summarizes the results of this literature search and rank orders the antecedents by the number of previous studies that support the relationship.

Table 1. Antecedents influencing each of the four stages

\begin{tabular}{lcc}
\hline Stage 1-Consumer's overall evaluation of the foreign product: & Frequency & \% of Studies \\
Country-of-origin image & 48 & 33.1 \\
Evaluation of specific product attributes & 14 & 9.7 \\
Consumer ethnocentrism & 12 & 8.3 \\
Brand image & 10 & 6.9 \\
Animosity & 5 & 3.4 \\
Product price & 4 & 2.8 \\
\hline Stage 2-Consumer's attitude towards the foreign product: & 12 & 8.3 \\
Country-of-origin image & 11 & 7.6 \\
Consumer ethnocentrism & 1 & 0.7 \\
Animosity & & 1 \\
\hline Stage 3-Consumer's intention to buy the foreign product: & 15 \\
Country-of-origin image & 12 & 10.3 \\
Animosity & 11 & 8.3 \\
Consumer ethnocentrism & 1 & 7.6 \\
Product price & & 0.7 \\
\hline Stage 4-Consumer's purchase of the foreign product: & & 2.1 \\
Consumer ethnocentrism & 5 & 0.7 \\
Country-of-origin image & & \\
Animosity & & 3.4 \\
\hline
\end{tabular}

While the earliest article reviewed was published in 1967, approximately 67 percent of the articles were published after 1999, providing evidence of the growing relevance of this research stream. The overwhelming majority of these articles were published in marketing and international business publications; however there were some studies found in management and cross-disciplinary journals. Aside from identifying the variables that have been theorized to influence the aforementioned stages leading towards foreign product purchase, the 
literature review also indicates that most researchers have not attempted to develop and test a comprehensive framework that incorporates these main determinants into one model. Only three of the 145 studies (Janda \& Rao, 1997; Rezvani et al., 2012; Samiee, 1994) were conceptual models that focused heavily upon the effects of country-of-origin image variable; however there was no evidence that these models were not tested in future research. The other 142 articles mainly centered around one or two variables of interest that impacted one of the specific stages investigated in this study.

\subsection{Conceptual Model and Hypotheses}

This study attempts to model the influences of primary antecedents upon the first three stages of the foreign product purchase process, namely the consumer's evaluation of the product, his or her attitude towards the product, and his or her willingness to purchase it. In developing this integrative model, the study incorporates several components designed to increase the parsimony of the framework while maintaining internal consistency and applicability. Due to the difficulties associated with measuring consumer purchase of products, purchase intention variables (e.g., willingness to buy, reluctance to buy, and likelihood of purchase) oftentimes serve as a viable proxy for the actual purchase (Han, 1988; Liefeld, 1993; Klein, Ettenson, \& Morris, 1998; Suh \& Kwon, 2002).

By examining the overall or universal product image from certain foreign countries, the product-specific constructs (e.g., brand image, product price, and specific product attributes) that were identified in the literature review are not examined within this study. Figure 1 illustrates the conceptual framework of the construct relationships identified and supported by the literature review. This framework consists of the primary variables affecting the first three stages of the consumer purchase decision process. Note that the solid arrows represent positive direct relationships and dashed arrows denote negative direct relationships, as stated in the hypotheses proposed in this study.

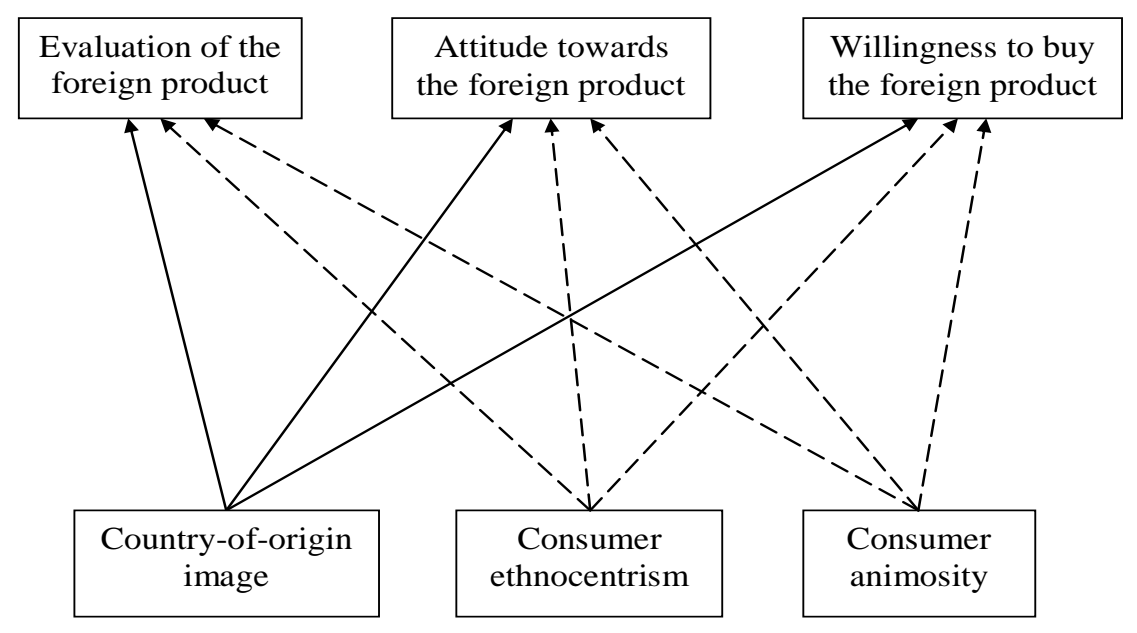

Figure 1. Conceptual model of the country-related influences

The causal paths within the framework represent main effects between key variables and each of the three distinct stages that serve as the theoretical foundation for this model. Three country-related antecedents were identified within the literature search as having profound influence when consumers are evaluating, forming attitudes toward, and intending to purchase foreign products. Strong associations between products and their countries-of-origin have been well established in consumer research (e.g., Brijs, Bloemer, \& Kasper, 2011; Chinen, Jun, \& Hampton, 2000; Huddleston, Good, \& Stoel, 2001; Hui \& Zhou, 2002; Orbaiz \& Papadopoulos, 2003; Peris, Newman, Bigne, \& Chansarkar, 1993; Teas \& Agarwal, 2000; Uddin, Parvin, \& Rahman, 2013; Wang, Barnes, \& Ahn, 2012). These studies strongly support the notion that country-of-origin image affects all three stages under investigation in this study; therefore the following three hypotheses are proposed:

H1: Country-of-origin image positively influences the consumer's evaluation of the foreign product.

$\mathrm{H} 2$ : Country-of-origin image positively influences the consumer's attitude towards the foreign product.

H3: Country-of-origin image positively influences the consumer's willingness to buy the foreign product. 
Secondly, consumer ethnocentrism has also received widespread attention within the research community and exhibits similar influences as country-of-origin image upon the purchase decision process (e.g., Sharma, 2011; Klein, 2002; Maher, Clark, \& Maher 2010; Suh \& Kwon 2002). Consumer ethnocentrism refers to "the beliefs held by [a nation's] consumers about the appropriateness, indeed morality, of purchasing foreign-made products. From the perspective of ethnocentric consumers, purchasing imported products is wrong because, in their minds, it hurts the domestic economy, causes loss of jobs, and is plainly unpatriotic" (Shimp \& Sharma, 1987, p. 280). Given that the following relationships have received support from past research, this study proposes threes hypotheses relating to the effects of consumer ethnocentrism upon all three stages (i.e., product evaluation, attitude formation, and purchase intention):

H4: Consumer ethnocentrism negatively influences the consumer's evaluation of the foreign product.

H5: Consumer ethnocentrism negatively influences the consumer's attitude towards the foreign product.

H6: Consumer ethnocentrism negatively influences the consumer's willingness to buy the foreign product.

The last antecedent, consumer animosity towards a foreign country, is the least studied variable among all of the constructs proposed in this framework, but is quickly gaining attention as an important variable in consumer research (e.g., Klein, Ettenson, \& Morris, 1998; Maher, Clark, \& Maher, 2010; Nijssen \& Douglas, 2004; Riefler \& Diamantopoulos, 2007; Witkowski, 2000). Animosity is referred to as consumer anger that is potentially generated from military, political or economic events (Klein, Ettenson, \& Morris 1998). While previous studies have produced mixed results when assessing the consequences of animosity, it has been found to have some level of influence during the product evaluation (e.g., Huang, Phau, \& Lin, 2010; Urbonavicius, Dikcius, Gineikiene, Degutis, \& Urbonavicius, 2010) and attitude formation stages (e.g., Leong et al., 2008), however the majority of the research indicates that animosity strongly affects the consumer's purchase intention of foreign goods (e.g., Cui, Wajda, \& Hu, 2012; Klein, 2002; Maher \& Mady, 2010; Mostafa, 2010; Nijssen \& Douglas, 2004). Given that the effects of animosity have received mixed support in previous studies, the following hypotheses will be tested to provide additional insight about animosity while in the presence of the other two country-related predictors. These last three hypotheses are formulated as:

H7: Consumer animosity negatively influences the consumer's evaluation of the foreign product.

H8: Consumer animosity negatively influences the consumer's attitude towards the foreign product.

H9: Consumer animosity negatively influences the consumer's willingness to buy the foreign product.

\section{Method}

\subsection{Pilot Study}

This study attempts to analyze and compare consumer perceptions of, attitude towards, and willingness to buy foreign products from three countries that vary by culture and geographic location. Previous research and relevant current events indicate that the three countries analyzed within this study (i.e., France, Japan, and Mexico) are assumed to vary with regards to their overall country-of-origin image and as sources of animosity among U.S. consumers; however these assumptions require verification of their validity as acceptable stimuli. To pretest these variances, a pilot study was conducted to determine noticeable differences among these countries in terms of variation among U.S. consumers for these two variables of interest. A total of 71 respondents from a major university completed the questionnaire survey for the pilot study. Six of the respondents were dropped from the sample due to their foreign national citizenship, leaving a testable sample of 65 U.S. respondents. The survey itself consisted of established scale items for each variable tested and the respondents self-reported their beliefs of, attitudes toward, and willingness to buy foreign goods from one of the countries of analysis.

As expected, Japan, Mexico, and France generated varying degrees of both national image and animosity from the U.S. respondents. For example, as an outcome of the French opposition towards the U.S. wars in the Middle East, the high level of anti-French sentiments among U.S. citizens is far outweighs their average animosity levels toward Japan. Strong U.S. sentiments towards illegal Mexican immigration tend to elicit high levels of animosity among many U.S. consumers. With regards to country-of-origin image among U.S. consumers, France and Japan typically elicit more favorable appeal than Mexico when considering their overall perceptions of goods. These three countries also represent geographically distinct and cultural diverse nations, expanding the scope of the study beyond the typical single country investigations.

\subsection{Measures}

As stated earlier, the constructs in this study were measured using established scales from previous research studies. The consumer's overall evaluation of the foreign product is measured by six items on a Likert scale 
anchored by 'strongly disagree-strongly agree' (Klein, Ettenson, \& Morris, 1998; Wood \& Darling, 1993). The consumer's attitude towards the foreign product consists of three items on a semantic differential scale anchored by 'bad-good', 'negative-positive,' and 'unfavorable-favorable' (Osgood, Suci, \& Tannenbaum, 1957; Simonin $\&$ Ruth, 1998). The consumer's willingness to buy the foreign product is measured by six items on a Likert scale anchored by 'strongly disagree-strongly agree' (Darling \& Arnold, 1988; Darling \& Wood, 1990).

The scales for the three country-related variables were borrowed from previous work as well. The consumer ethnocentrism scale is the reduced version of the original CET scale (Shimp \& Sharma, 1987), containing only ten Likert scale items anchored by 'strongly disagree-strongly agree' (Douglas \& Nijssen, 2003; Netemeyer, Durvasula, \& Lichtenstein, 1991). While country-of-origin image is typically assessed along three attribute dimensions (Pisharod \& Parameswaran, 1992), past research has commonly measured consumer perceptions and purchase intention towards all products in general from a particular country (e.g., Papadopoulos, Heslop, \& Bamossy, 1990; Suh \& Kwon, 2002), generating an overall assessment of products from the country. Following suit, this study eliminated scale items that referred to specific product attributes; therefore the country-of-origin image scale was reduced to thirty Likert scale items along the two remaining dimensions (general country attributes and general product attributes) anchored by 'not at all appropriate-most appropriate'. Animosity consists of nine Likert scale items anchored by 'strongly disagree-strongly agree' (Klein, Ettenson, \& Morris, 1998). Given that the sample needed to solely consist of U.S. consumers, basic demographic variables were also assessed (e.g., age, gender, and country of citizenship) to serve as a screening process to determine the suitability of each respondent.

\subsection{Main Study}

An initial sample of 446 respondents was recruited from a U.S. university to participate in the main study. Each respondent randomly received one of the three surveys addressing their perceptions of products from a particular country. A total of 149, 163, and 134 respondents had answered questions concerning products from France, Japan, and Mexico, respectively. After eliminating those respondents who did not identify themselves as U.S. citizens, 434 respondents were qualified for further examination. This remaining sample was comprised of approximately $72 \%$ Caucasian respondents with an average age of 29 years. Nearly 62 percent of the respondents were female and all respondents accessed the questionnaires through an online survey link. As compensation, the university students earned extra credit points towards an undergraduate course for participating in this study.

To test the nine hypotheses, multivariate analysis (i.e., MANOVA) was selected due to the fact that it permits detection of the main effect of individual predictors upon multiple outcome variables. This analytical tool has been utilized extensively in previous studies involving consumer ethnocentrism and country-or-origin research (Wong, Polonsky, \& Garma, 2008). Given that this study is assessing the impact of three predictors upon three separate dependent variables (i.e., foreign product evaluation, consumer attitude towards the foreign product, and willingness to buy the foreign product), MANOVA allows the simultaneous testing for significance with the inclusion of all three antecedents of interest (i.e., country-of-origin image, consumer ethnocentrism, and animosity) in the analysis.

\section{Results}

With regards to the measurements used in this study, reliability was determined to be at acceptable levels (i.e., above the 0.80 cutoff) for all variables assessed in this study. The Cronbach alpha coefficients were reported as 0.92 for country-of-origin image, 0.94 for consumer ethnocentrism, 0.90 for animosity, 0.85 for product evaluation, 0.97 for attitude towards the product, and 0.87 for willingness to buy. As previously stated, a multivariate analysis was conducted to test for significance of the three country-related independent variables upon each of the three dependent variables of interest. Table 2 illustrates the $F$ values and significance testing results for each of the hypothesized relationships.

The adjusted R Squared values were computed as 0.57 for the product evaluation stage, 0.42 for the attitude formation stage, and 0.63 at the willingness to buy stage, indicating that an acceptable amount of variance is explained by the proposed model. As expected, there is significant evidence that country-of-origin image positively influences all three stages at the 0.05 level, supporting $\mathrm{H} 1, \mathrm{H} 2$, and $\mathrm{H} 3$. As for $\mathrm{H} 4$, the negative influence of consumer ethnocentrism upon foreign product evaluation is not significant at the 0.05 level, which contradicts findings from previous research (e.g., Ahmed \& d'Astous, 1996; Orbaiz \& Papadopoulos, 2003; Uddin, Parvin, \& Rahman, 2013). The results do suggest that consumer ethnocentrism negatively influences both consumer attitudes and purchase intentions, providing statistical support for $\mathrm{H} 5$ and H6. As for the three hypotheses concerning consumer animosity, the results supported H9 (direct influence upon willingness to buy), 
but do not provide support for either $\mathrm{H} 7$ or $\mathrm{H} 8$ at the 0.05 level. Table 3 provides a summary display of the significance testing results at the .05 level for all nine hypotheses in this study.

Table 2. Summary of multivariate analysis results

\begin{tabular}{|c|c|c|c|c|c|c|}
\hline Source & Dependent Variable & Sum of Squares & $\mathrm{df}$ & Mean Square & F value & Sig. \\
\hline \multirow[t]{3}{*}{ Consumer ethnocentrism } & Evaluation & 1.501 & 1 & 1.501 & 3.319 & .069 \\
\hline & Attitude & 4.044 & 1 & 4.044 & 4.588 & $.033 *$ \\
\hline & Willingness to buy & 65.979 & 1 & 65.979 & 118.179 & $.000 *$ \\
\hline \multirow[t]{3}{*}{ Animosity } & Evaluation & 1.006 & 1 & 1.006 & 2.223 & .137 \\
\hline & Attitude & 2.855 & 1 & 2.855 & 3.239 & .073 \\
\hline & Willingness to buy & 54.887 & 1 & 54.887 & 98.312 & $.000 *$ \\
\hline \multirow[t]{3}{*}{ Country-of-origin image } & Evaluation & 171.605 & 1 & 171.605 & 379.463 & $.000 *$ \\
\hline & Attitude & 157.872 & 1 & 157.872 & 179.112 & $.000 *$ \\
\hline & Willingness to buy & 17.871 & 1 & 17.871 & 32.011 & $.000 *$ \\
\hline \multirow[t]{3}{*}{ Error } & Evaluation & 194.460 & 430 & .452 & & \\
\hline & Attitude & 379.008 & 430 & .881 & & \\
\hline & Willingness to buy & 240.069 & 430 & .558 & & \\
\hline \multirow[t]{3}{*}{ Total } & Evaluation & 8496.472 & 434 & & & \\
\hline & Attitude & 8315.444 & 434 & & & \\
\hline & Willingness to buy & 10831.472 & 434 & & & \\
\hline \multirow[t]{3}{*}{ Corrected Total } & Evaluation & 454.890 & 433 & & & \\
\hline & Attitude & 652.403 & 433 & & & \\
\hline & Willingness to buy & 645.974 & 433 & & & \\
\hline
\end{tabular}

Note. * Significant at $\mathrm{p}<.05$.

Table 3. Summary of the hypotheses testing results

\begin{tabular}{ll}
\hline Hypotheses & Test Results \\
\hline H1: Country-of-origin image positively influences the consumer's evaluation of the foreign product. & Supported \\
H2: Country-of-origin image positively influences the consumer's attitude towards the foreign product. & Supported \\
H3: Country-of-origin image positively influences the consumer's willingness to buy the foreign product. & Supported \\
H4: Consumer ethnocentrism negatively influences the consumer's evaluation of the foreign product. & Not supported \\
H5: Consumer ethnocentrism negatively influences the consumer's attitude towards the foreign product. & Supported \\
H6: Consumer ethnocentrism negatively influences the consumer's willingness to buy the foreign product. & Supported \\
H7: Consumer animosity negatively influences the consumer's evaluation of the foreign product. & Not supported \\
H8: Consumer animosity negatively influences the consumer's attitude towards the foreign product. & Not supported \\
H9: Consumer animosity negatively influences the consumer's willingness to buy the foreign product. & Supported \\
\hline
\end{tabular}

\section{Conclusion}

This study provides insight concerning the effects of three key antecedents-animosity, consumer ethnocentrism, and country-of-origin image - upon the three stages leading to the purchase of foreign goods. While all three variables are shown to influence this process, the nature of their influences is vastly different. Country-of-origin image tends to have a direct positive influence at all stages of the process. In contrast, consumer ethnocentrism tends to negatively impact the latter stages (i.e., attitude formation and willingness to buy). Given that this study 
found no evidence of a direct relationship between consumer ethnocentrism and foreign product evaluation, this may indicate that consumers can develop positive evaluations of foreign products, but their high levels of consumer ethnocentrism prevents them from ever purchasing these products. Similar results were found for consumer animosity, suggesting that consumers harboring animosity towards a foreign country may positively evaluate or form positive attitudes about products from that country, but are less willing to purchase the goods due to their felt animosity.

Since a consumer's cognitive associations with a country and its products tend to influence the overall evaluation of the product, marketers may manipulate the amount of country-of-origin information when advertising, promoting or educating consumers about new product offerings. They can deliberately emphasize the country-of-origin information on the package and in ads if the country-of-origin is vastly perceived in a favorable light by the consumers in that market. This information can also be de-emphasized to avert consumer's attention from an unattractive country-of-origin and towards more attractive product attributes.

To combat the negative effects consumer ethnocentrism or animosity, the most plausible route for the marketer to take would be to make the product appear as local as possible. The marketer could change the brand name to a word that is meaningful in the native language and advertisements for the product should primarily portray native actors and actresses, a local soundtrack and culturally recognizable lifestyles, aesthetics, and events within the ads. Testimonials and product endorsements should be sought from native celebrities in the sports and entertainment venues or from local opinion leaders and professionals, depending on the nature of the product offerings. These proposed marketing actions may change the image of the product in the minds of the local consumers and subdue the negative effects of country-related variables like those assessed in this study.

\section{References}

Ahmed, S., \& d'Astous, A. (1996). Country-of-origin and brand effects: a multi-dimensional study and multi-attribute study. Journal of International Consumer Marketing, 9(2), 93-115. http://dx.doi.org/10.1300/J046v09n02_05

Bandyopadhyay, S., \& Banerjee, B. (2002). A country of origin analysis of foreign products by Indian consumers. Journal of International Consumer Marketing, 15(2), 85-109. http://dx.doi.org/10.1300/J046v15n02_06

Brijs, K., Bloemer, J., \& Kasper, H. (2011). Country-image discourse model: unraveling meaning, structure, and function of country images. Journal of Business Research, 64, 1259-1269. http://dx.doi.org/10.1016/j.jbusres.2011.01.017

Chinen, K., Jun, M., \& Hampton, G. M. (2000). Product quality, market presence, and buying behavior: aggregate images of foreign products in the U.S. Multinational Business Review, Spring, 29-38.

Cui, A. P., Wajda, T. A., \& Hu, M. Y. (2012). Consumer animosity and product choice: might price make a $\begin{array}{llll}\text { difference? } & \text { Journal } & \text { Marketing, } & \text { 29(7), }\end{array}$ http://dx.doi.org/10.1108/07363761211275009

Darling, J. R., \& Arnold, D. R. (1988). Foreign consumers' perspective of the products and marketing practices of the United States versus selected European countries. Journal of Business Research, 17(3), 237-248. http://dx.doi.org/10.1057/palgrave.jibs.8490827

Darling, J. R., \& Wood, V. R. (1990). A longitudinal study comparing perceptions of U.S. and Japanese consumer products in a third neutral country: Finland 1975 to 1985. Journal of International Business Studies, 21(3), 427-450. http://dx.doi.org/10.1057/palgrave.jibs.8490827

Demir, O. (2013). Is Turkey far from BRIC countries? International Journal of Business and Social Science, 4(5), $136-141$.

Douglas, S. P., \& Nijssen, E. J. (2003). On the use of 'borrowed' scales in cross-national research: a cautionary note. International Marketing Review, 20(6), 621-642. http://dx.doi.org/10.1108/02651330310505222

Fishbein, M., \& Ajzen, I. (1975). Belief, attitude, intention, and behavior: an introduction to theory and research. Reading, MA: Addison-Wesley.

Han, C. M. (1988). The role of consumer patriotism in the choice of domestic versus foreign products. Journal of Advertising Research, 28, 25-31.

Huang, Y. A., Phau, I., \& Lin, C. (2010). Consumer animosity, economic hardship, and normative influence. European Journal of Marketing, 44(7/8), 909-937. http://dx.doi.org/10.1108/03090561011047463

Huddleston, P., Good, L. K., \& Stoel, L. (2001). Consumer ethnocentrism, product necessity and Polish 
consumers' perceptions of quality. International Journal of Retail \& Distribution Management, 29(5), 236-246. http://dx.doi.org/10.1108/09590550110390896

Hui, M. K., \& Zhou, L. (2002). Linking product evaluations and purchase intention for country-of-origin effects. Journal of Global Marketing, 15(3/4), 95-116. http://dx.doi.org/10.1300/J042v15n03_05

Janda, S., \& Rao, C. P. (1997). The effect of country-of-origin related stereotypes and personal beliefs on product evaluation. Psychology \& Marketing, http://dx.doi.org/10.1002/(SICI)1520-6793(199710)14:7<689::AID-MAR4>3.0.CO;2-C

Klein, J. G. (2002). Us versus them, or us versus everyone? Delineating consumer aversion to foreign goods. Journal of International Business Studies, 33(2), 345-363. http://dx.doi.org/10.1057/palgrave.jibs.8491020

Klein, J. G., Ettenson, R. E., \& Morris, M. D. (1998). The animosity model of foreign product purchase: an empirical test on the People's Republic of China. Journal of Marketing, 62(1), 89-100. http://dx.doi.org/10.2307/1251805

Leong, S. W., Cote, J. A., Ang, S. H., Tan, S. J., Jung, K., Kau, A. K., \& Pornpitakpan, C. (2008). Understanding consumer animosity in an international crisis: nature, antecedents, and consequences. Journal of International Business Studies, 39, 996-1009. http://dx.doi.org/10.1057/palgrave.jibs.8400392

Li, W. K., Monroe, K. B., \& Chan, D. K. S. (1994). The effects of country of origin, brand, and price information: a cognitive-affective model of buying intentions. In C. T. Allen \& D. R. John (Eds.), NA-Advances in Consumer Research (vol. 21, pp. 449-457). Provo, UT.

Liefeld, J. P. (1993). Consumer use of country-of-origin information in product evaluations: evidence from experiments. In N. Papadopoulos \& L. A. Heslop (Eds.), Product and Country Images: Impact and Role in International Marketing (pp. 117-156). New York, NY. The Haworth Press, Inc.

Maher, A. A., \& Mady, S. (2010). Animosity, subjective norms, and anticipated emotions during an international crisis. International Marketing Review, 27(6), 630-651. http://dx.doi.org/10.1108/02651331011088263

Maher, A. A., Clark, P., \& Maher, A. (2010). International consumer admiration and the persistence of animosity. Journal of Consumer Marketing, 27(5), 414-424. http://dx.doi.org/10.1108/07363761011063312

Mostafa, M. M. (2010). A structural equation analysis of the animosity model of foreign product purchase in Egypt. Global Business Review, 11(3), 347-363. http://dx.doi.org/10.1177/097215091001100303

Mowen, J. C. (1995). Consumer behavior (4th ed.). Englewood Cliffs, NJ: Prentice Hall.

Netemeyer, R. G., Durvasula, S., \& Lichtenstein, D. R. (1991). A cross-national assessment of the reliability and validity of the CETSCALE. Journal of Marketing Research, 28(3), 320-327. http://dx.doi.org/10.2307/3172867

Nijssen, E. J., \& Douglas, S. P. (2004). Examining the animosity model in a country with a high level of foreign trade. International Journal of Research in Marketing, 21(1), $23-38$. http://dx.doi.org/10.1016/j.ijresmar.2003.05.001

Orbaiz, L. V., \& Papadopoulos, N. (2003). Toward a model of consumer receptivity of foreign and domestic products. Journal of International Consumer Marketing, 15(3), 101-126. http://dx.doi.org/10.1300/J046v15n03_06

Papadopoulos, N., Heslop, L. A., \& Bamossy, G. (1990). A comparative image analysis of domestic versus imported products. International Journal of Research in Marketing, 7(4), $283-294$. http://dx.doi.org/10.1016/0167-8116(90)90005-8

Peris, S. M., Newman, K., Bigne, E., \& Chansarkar, B. (1993). Aspects of Anglo-Spanish perceptions and product preferences arising from 'country of origin' image. International Journal of Advertising, 12, $131-142$.

Pisharod, R. M., \& Parameswaran, R. (1992). Confirmatory factor analysis of a country-of-origin scale: initial results. In J. F. Sherry, Jr. \& B. Sternthal (Eds.), NA-Advances in Consumer Research (vol. 19, pp. 706-714). Provo, UT.

Rezvani, S., Dehkordi, G. J., Rahman, M. S., Fouladivanda, F., Habibi, M., \& Eghtebasi, S. (2012). A conceptual study on the country of origin effect on consumer purchase intention. Asian Social Science, 8(12), $205-215$. http://dx.doi.org/10.5539/ass.v8n12p205

Riefler, P., \& Diamantopoulos, A. (2007). Consumer animosity: a literature review and a reconsideration of its 
measurement. International Marketing $\quad$ Review, $\quad$ 24(1), http://dx.doi.org/10.1108/02651330710727204

Samiee, S. (1994). Customer evaluation of products in a global market. Journal of International Business Studies, Third Quarter, 579-604. http://dx.doi.org/10.1057/palgrave.jibs.8490213

Sharma, P. (2011). Country of origin effects in developed and emerging markets: exploring the contrasting roles of materialism and value consciousness. Journal of International Business Studies, 42, $285-306$. http://dx.doi.org/10.1057/jibs.2010.16

Shimp, T. A., \& Sharma, S. (1987). Consumer ethnocentrism: construction and validation of the CETSCALE. Journal of Marketing Research, 24, 280-289. http://dx.doi.org/10.2307/3151638

Simonin, B. L., \& Ruth, J. A. (1998). Is a company known by the company it keeps? Assessing the spillover effects of brand alliances on consumer brand attitudes. Journal of Marketing Research, 35(1), 30-42. http://dx.doi.org/10.2307/3151928

Suh, T., \& Kwon, I. G. (2002). Globalization and reluctant buyers. International Marketing Review, 19(6), 663-680. http://dx.doi.org/10.1108/02651330210451962

Teas, R. K., \& Agarwal, S. (2000). The effects of extrinsic product cues on consumers' perceptions of quality, sacrifice, and value. Journal of the Academy of Marketing Science, 28(2), 278-290. http://dx.doi.org/10.1177/0092070300282008

Uddin, J., Parvin, S., \& Rahman, M. L. (2013). Factors influencing importance of country of brand and country of manufacturing in consumer product evaluation. International Journal of Business and Management, 8(4), 65-74. http://dx.doi.org/10.5539/ijbm.v8n4p65

Ulgado, F. M., \& Lee, M. (1998). The Korean versus American marketplace: consumer reactions to foreign $\begin{array}{llll}\text { products. } & \text { Psychology } \quad \text { Marketing, } & \text { 15(6), }\end{array}$ http://dx.doi.org/10.1002/(SICI)1520-6793(199809)15:6<595::AID-MAR7>3.0.CO;2-1

Urbonavicius, S., Dikcius, V., Gineikiene, J., Degutis, M., \& Urbonavicius, S. (2010). Country of origin effects in the context of transformations: nostalgia, ethnocentrism and animosity. Transformations in Business \& Economics, 1(19), 182-202.

Wang, C. L., Li, D., Barnes, B. R., \& Ahn, J. (2012). Country image, product image and consumer purchase intention: evidence from an emerging economy. International Business Review, 21, 1041-1051. http://dx.doi.org/10.1016/j.ibusrev.2011.11.010

Witkowski, T. (2000). Effects of animosity toward China on willingness to buy Chinese products. In G. McLean, E. Kaynak, \& O. Aliaga (Eds.), The International Management Development Association (pp. 470-477). Hummelstown, PA.

Wong, C. Y., Polonsky, M. J., \& Garma, R. (2008). The impact of consumer ethnocentrism and country of origin sub-components for high involvement products on young Chinese consumers' product assessments. Asia Pacific Journal of Marketing and Logistics, 20(4), 455-478. http://dx.doi.org/10.1108/13555850810909759

Wood, V. R., \& Darling, J. R. (1993). The marketing challenges of the newly independent republics: product competitiveness in global markets. International Marketing Review, 1(1), 77-102.

Zajonc, R. B. (1984). On the primacy of affect. American Psychologist, 39(2), 117-123. http://dx.doi.org/10.1037/0003-066X.39.2.117

\section{Copyrights}

Copyright for this article is retained by the author(s), with first publication rights granted to the journal.

This is an open-access article distributed under the terms and conditions of the Creative Commons Attribution license (http://creativecommons.org/licenses/by/3.0/). 